\title{
Effect of Cold Compress on Reduction of Perineal Pain in Postpartum Mothers in the Maternity Clinic of Ar-Rahmah Ogan Ilir Palembang in 2019
}

\author{
1st Rosmiarti \\ Lecturer of the Midwifery \\ Study Program of STIKes \\ Muhammadiyah Palembang \\ rosmarti5474@yahoo.com
}

\begin{abstract}
A mother who has undergone labor by getting a perineal wound will feel pain, pain that is felt in every mother with a perineal wound causing unpleasant effects such as pain and fear of moving so that many mothers with perineal injury rarely want to move postpartum so that it can result in many problems include uterine sub involution, non-smooth discharge of lochea, and postpartum hemorrhage. Women with a perineal wound will experience pain and discomfort (Tamsuri in Rahmawati, 2013). Objective. Purpose to find out the effect of cold compresses on the reduction of perineal wound pain in postpartum mothers at the Ar-Rahmah Indralaya Ogan Ilir Maternity Clinic in Palembang in 2019. Research Methods This sampling technique was carried out using consecutive sampling techniques. With a sample size of 35 respondents in the postpartum maternity clinic Ar-Rahma Ogan Ilir Palembang in 2019, the tool used was a questionnaire to determine the effect of cold compresses on perineal wound pain with the Numerical Rating Scale (NRS) used to assess the intensity or severity of pain and to provide pain with the client's complete freedom to identify the severity of pain and be analyzed by the T-paired test. Result, Univariate analysis results showed that from an average of 3 treatments it was found that respondents who felt pain before treatment experienced more pain in the moderate category $(52 \%)$ and severe pain $(23 \%)$ and mild pain $(25 \%)$. Respondents who were taken after treatment were more likely to experience mild pain $(43 \%)$, moderate pain $(42 \%)$, and severe pain $(15 \%)$. The results of the bivariate analysis showed that respondents had a significant relationship between the dependent variable and the independent variable. In the parametric statistical research data the Wilcoxon test results obtained a significance value of $0,000(p<0.05)$ meaning that there was an influence of cold compresses on perineal wound pain at the Ar-Maternity Clinic Rahma Ogan Ilir Palembang in 2019 From the paired samples test that the significance value of $\rho$ value is 0,000 , it means that it is smaller than $\alpha$ (0.05), which shows that there is an influence of cold compresses on perineal wound pain in the Ar-Rahma Ogan Ilir Palembang Maternity Clinic 2019. Conclusion. Discussion Based on the results of the study, researchers assumed pain management with non-pharmacology could reduce pain in the perineal wound by using cold compress techniques. Cold compresses on pain in the perineal wound are very influential, and their physiological impact is vasoconstriction in blood vessels, reducing pain, and decreasing the activity of nerve endings in the muscles.
\end{abstract}

Keywords-Cold Compress, Perineal Pain, Postpartum Mothers, Maternity

\section{INTRODUCTION}

Perineal injury is an injury that occurs in the perineum during labor, and $70 \%$ occurs in women who give birth vaginal (Chapman, 2006). The puerperium or puerperium is a period after parturition is complete until the recovery of uterine organs as before pregnancy. The duration of the puerperium is about 6-8 weeks (Abidin, 2011).

The puerperium is still a vulnerable period for the survival of new mothers in labour. According to the 2010 SP Afifah et al. (2011), most maternal deaths occur during the puerperium so that postpartum health services play an essential role in efforts to reduce maternal mortality. Postnatal care is health services provided to mothers during a period of 6 hours to 42 days after delivery. The Ministry of Health determines the postpartum service program or contact mothers stated in the indicators (Riskesdas, 2013).

When puerperium (puerperium) which lasts for six weeks or 42 days, is the time required for the recovery of uterine organs in a healthy state. Two crucial events were encountered in the puerperium, namely uterine involution and lactation process. (Ida Ayu Candranita Manuaba, 2010). Perineal tears occur in almost all first deliveries and not infrequently in subsequent deliveries. Perineal tears generally occur in the middle line and are usually broad when the fetal head is born too fast, the angle of the pubic arch is smaller than usual, the head of the fetus passes through the lower flank with a larger size than the brummatic subpoksipito circumcum (Sukarni \& Margareth in Timbawa, 2015).

Pain can be controlled by two methods, namely pharmacological and non-pharmacological. Pharmacological pain relief methods are methods of relieving pain by using chemical drugs, among others by administering inhalation analgesia, opioid analgesia, and regional anaesthesia, while nonpharmacological methods are natural pain relief methods without the use of chemical drugs. Pain management with cold compress action is a method that can be applied to help comfort the puerperal mother to reduce pain. Benefits of cold compresses include reducing blood flow to the area of the wound to reduce the risk of bleeding and oedema, and cold compresses cause analgesic effects by slowing the speed of nerve delivery so that the pain impulses that reach the brain will be less. Another mechanism that might work is 
that cold compresses become dominant and reduce pain (Judha, 2012).

Cold compress is a procedure of placing a cold object on the outside of the body. The physiological impact is vasoconstriction in blood vessels, reducing pain, and decreasing nerve end activity in muscles. From the results of Rahmawati's research (2013), that after being given a cold compress on the perineum, most postpartum mothers experience mild pain levels. The use of cold compresses has been proven to be able to relieve pain, and cold therapy has an analgesic effect by slowing the speed of nerve delivery so that the pain impulses that reach the brain are less (Rahmawati, 2013).

Ice therapy can reduce prostaglandins which strengthen the sensitivity of pain receptors and other subcutaneous at the site of injury by inhibiting the inflammatory process. To be effective, ice can be placed at the site of injury immediately after the injury (Andarmoyo Sulistyo, 2013).

The purpose of this research is to know the effect of cold compresses on the reduction of perineal wound pain in postpartum mothers at the Ar-Rahmah Indralaya Maternity Clinic, Ogan Ilir Palembang in 2019.

\section{METHOD}

This type of research used in this study is a quasiexperiment. The research design used was one group comparative pretest-posttest design, namely the research design that contained pre-test before being given treatment and post-test after being treated. Thus it can be known more accurately because it can be compared with held before being given treatment (Sugiyono, 2001)

One group's Pre-test - Post-test design formula:

\section{Information:}

\section{$01 \mathrm{X} 02$}

- 01 is a pre-test

- $\mathrm{X}$ is a treatment

- 02 is a post-test

The first thing in experimenting using a single sample design is done by asking the level of pain to the untreated sample called pre-test (01) after getting the pain level, then doing the treatment $(\mathrm{X})$ with the administration technique.

Cold compresses in the perineum for 10-15 minutes, then re-assess the level of pain after being given a cold compress (02), in the post-test will get pain scale data from experiments where the pain scale increases or there is no change at all. Compare) 1 and) 2 to determine how much difference arises if any as a result of the giving of experimental variables. Then the data is analyzed using ttest (Arikunto, 2002)

The tool used in this study was a questionnaire to determine the effect of cold compresses on pain in perineal wounds. There is also a Numerical Rating Scale (NRS) used to assess the intensity or severity of pain and give the client full freedom to identify the severity of pain. NRS is a popular pain scale and is more widely used in clinics, especially in acute conditions, measuring pain intensity before and after therapeutic intervention, easy to use and documented. To identify the effect of compresses both before and after the intervention was given, the Paired T-test was performed.

\section{RESULTS}

TABLE 1. DISTRIBUTED FREQUENCY BEFORE TREATMENT

\begin{tabular}{|c|c|c|c|}
\hline No & Perinela injury & Amount & Percentage $\%$ \\
\hline 1 & Medium & 16 & $46 \%$ \\
\hline 2 & weight & 4 & $11 \%$ \\
\hline 3 & Lighweight & 15 & $43 \%$ \\
\hline \multicolumn{2}{|c|}{ Total } & 35 & $100 \%$ \\
\hline \multicolumn{2}{|c|}{ REATMENT } & \multicolumn{2}{|c|}{ FREQUENCIES } \\
\hline No & Perinela injury & Amount & Percentage $\%$ \\
\hline 1 & Lightweight & 25 & $71 \%$ \\
\hline 2 & Medium & 10 & $29 \%$ \\
\hline 3 & weight & 0 & $0 \%$ \\
\hline \multicolumn{2}{|c|}{ Total } & 35 & $100 \%$ \\
\hline
\end{tabular}

\section{BIVARIATE RESULTS}

Shows that the significance value of $\rho$ value 0.00 is greater than $\alpha(0.05)$, it can be concluded that there is an effect of cold compresses on the reduction of perineal wounds pain in postpartum mothers. After doing the Wilcoxon Signed Rank Test and statistical analysis using paired sample T-test to determine the relationship of two variants know the relationship of two variables. In this study, researchers wanted to know the difference in perineal wound pain before and after a compress was made. The differences can be seen in Table 3 below:

TABLE 3. PAIRED SAMPLES CORRELATIONS

\begin{tabular}{|l|l|r|r|r|}
\hline \multicolumn{2}{|l|}{} & $\mathrm{N}$ & Correlation & \multicolumn{1}{c|}{ Sig. } \\
\hline Pair 1 & $\begin{array}{l}\text { Nyeri sebelum } \\
\text { diberikan intervensi } \\
\text { \& nyeri_setelah1 }\end{array}$ & 35 & .960 & .000 \\
\hline Pair 2 & $\begin{array}{l}\text { Nyeri_sebelum2 \& } \\
\text { Nyeri_setelah2 }\end{array}$ & 35 & .957 & .000 \\
\hline Pair 3 & $\begin{array}{l}\text { Nyeri_sebelum3 \& } \\
\text { Nyeri_setelah3 }\end{array}$ & 35 & .945 & .000 \\
\hline
\end{tabular}

This cold compress technique is used by compressing the wound area of the mother's perineum using ice-cold water or ice cubes with a temperature of $13 \mathrm{oC}$. Compressing is done for 10-15 minutes.

Effects of Cold Compresses on Perineal Wound Pain Univariate analysis results showed that respondents who felt pain before treatment experienced more pain in the moderate category $(52 \%)$ and severe pain $(48 \%)$. More respondents who were taken after the treatmentexperienced moderate pain $(52 \%)$, mild pain $(40 \%)$, and severe pain $(8 \%)$.

\section{DISCUSSION}

The results of the bivariate analysis showed that respondents had a significant relationship between the dependent variable and the independent variable. In the parametric statistical research data, the Wilcoxon test results obtained a significance value of $0,000(p<0.05)$ meaning that there was an influence of cold compresses on perineal wound pain at the Ar-Maternity Clinic. Rahma 
Ogan Ilir Palembang in 2019 From the paired samples test that the significance value of $\rho$ value is 0,000 means smaller than $\alpha(0.05)$, which shows that there is an effect of cold compresses on perineal wound pain at the ArRahma Ogan Ilir Maternity Clinic in Palembang in 2019.

This study is in line with research conducted by Siti Alfirdaus (2011) in BPM in Tuban Regency, who said that cold compresses affect the pain of perineal injury. After analyzing using the Wilcoxon test using consecutive sampling, pre-test and post-test and count manually obtained $\mathrm{w}$ count $=12 \mathrm{w}$ table $=40$, with a significance level $\rho=0.05 \mathrm{~W}$ count it is smaller than $\mathrm{W}$ table. This means that there is an effect of cold compresses on pain of perineal wounds in the puerperal mother. Given the treatment of cold compresses before experiencing moderate pain levels as much as $1260 \%$. and after being given a cold compress treatment, the pain level is reduced by as much as $15(75 \%)$.

That after being given a cold compress on the part of the perineum, most postpartum mothers experience mild pain levels. The use of cold compresses has been proven to be able to relieve pain, and cold therapy has an analgesic effect by slowing the speed of nerve delivery so that the pain impulses that reach the brain are less (Rahmawati, 2013).

This is in accordance with the theory of Potter \& Perry (2006), which states that cold compresses can relieve pain. This theory states that the workings of cold compresses are by releasing endorphins, thus blocking the transmission of larger and faster sensory A-beta nerve fibres. This process decreases pain transmission through $\mathrm{C}$ fibres and delta-A small in diameter so that the closed gates close the transmission of pain impulses.

Endorphin is a substance such as morphine produced by the body (including endogenous Chemicals) and has an intense concentration in the nervous system. This endorphin acts as an inhibitor of pain transmission by blocking the transmission of brain impulses and the spinal cord. Cold compresses are used to relieve pain by slowing the speed of nerve conduction, causing numbness and working as a counterirritant. Giving cold application measures can reduce pain and increase healing. Cold application is related to the slowing ability of pain nerves in channelling pain stimuli (Sulistiyani, 2009).

This research was supported by Yusniar's 2012 study entitled "Giving Cold Compress to Postpartum Mothers with Perineum Injury Influencing Pain Relief in Nirmala Clinic Medan" which states that there are significant results on giving cold compresses to wound pain.

Similar opinion regarding the results of this study was shown by Arsitya (2013) in his study entitled "Influence Giving Cold Compress against Reduction of Perineum Pain in BPS Kusni Srimarwati Dlingo Bantul Yogyakarta ". In this study, there was a significant effect of cold compresses on pain in perineal wounds.

\section{CONCLUSION}

Based on the results of the study, researchers assume pain management with non-pharmacology can reduce pain in the perineal wound by using cold compress techniques. Cold compresses on pain in the perineal wound are very influential, and their physiological impact is vasoconstriction in blood vessels, reducing pain, and decreasing the activity of nerve endings in the muscles.

\section{REFERENCES}

[1] Abidin., 2011 Asuhan kebidanan Masa Nifas. Yogyakarta: Pustaka Baru Press

[2] Andarmoyo, 2013. Konsep dan proses keperawatan nyeri , Yogyakarta, ar- Ruzz Media

[3] Arikunto, S. 2010. Prosedur Penelitian Suatu Pendekatan Praktik. Jakarta:

[4] Rineka Cipta.

[5] Ambarwarti dan Wulandari. 2010. Asuhan Kebidanan Nifas. Yogyakarta: Nuha Medika

[6] Judha, dkk. 2012. Teori Pengukuran Nyeri . Yogyakarta: Nuha Medika.

[7] Johnson. (2010). Buku Ajar Keperwatan Keluarga. Yogyakarta : Nuha medika

[8] Mander, R. (2003). Nyeri persalinan (terjemahan Bertha Sugiarto). Jakarta: Penerbit Buku Kedokteran EGC.

[9] Manuaba, I.B.G.,2010. Gawat Darurat Obstetri dan Ginekologi

[10] Potter \& Perry. 2009. Mengukur Nyeri. Jakarta: Salemba Medika

[11] Rahmawati, E. 2011. Pengaruh Kompres Dingin Terhadap Pengurangan Nyeri Luka Perineum Pada Masa Nifas. di BPS Siti Alfirdaus Kingking Kab. Tuban.

[12] Riset Kesehatan Dasar(Riskesdas). (2013). Badan Penelitian dan Pengembangan

[13] Kesehatan Kementerian RI tahun 2013.Diakses: 19 Oktober 2014, http://www.depkes.go.id/resources/download/general/Hasil\%20 Riskesdas\%20 2013.pdf. 